\title{
Histone Fold
}

National Cancer Institute

\section{Source}

National Cancer Institute. Histone Fold. NCI Thesaurus. Code C13421.

A protein structural element originally identified in the core histones. It is of the helixloop-helix type and is involved in protein-protein interactions via a "handshake" motif with a histone fold partner. Also involved in protein-DNA interactions. 